fatty acids, due to lack of lipase or bile salts. Hence there is a marked defect of absorption and no evidence of increased fatty acid absorption. The second group of fat absorption-defects usually shows a less marked decrease, 50-70 per cent being absorbed. Intraluminar emulsification is apparently normal. Consequently, hydrolysis and increased fatty acid absorption occur in the upper part of the intestine, giving rise to changes in gastric acidity and motility and increased mucous secretion. Decreased gastric acidity and motility and interference with absorption favour the upgrowth of intestinal flora; interference with carbohydrate absorption in particular provides an opportunity for fermentation. Heavy bacterial growth in the upper intestine may give rise to competition with the host for common essential nutrients. Thus, the sprue syndrome may arise from secondary changes which follow interference with the particulate absorption of fat and consequent increase of fatty acid absorption.

Dr. J. J. Elkes (Birmingham), reading a paper on the use of fat in intravenous alimentation, said that, theoretically, fat might be given either as soluble lipoprotein complexes comparable to the invisible fat of blood plasma or as finely dispersed triglyceride emulsions, similar to hyperlipæmic blood. Too little is known at present of the structure or functions of plasma lipoproteins to make it possible to use them. Finely divided oil-in-water emulsions, however, can be prepared relatively easily. Oil-inwater emulsions occurring in vivo consist essentially of triglycerides in a protein environment. Their stability is dependent upon the nature of the interfacial film. The composition of this film has been studied by observing changes in dispersion and electrophoretic mobility over a $p H$ range, or in the presence of enzymes, such as $C l$. welchii lecithinase. Characteristic flocculation patterns have been demonstrated. These are used for the comparison of artificial and natural emulsions.

Emulsions for intravenous alimentation must be proved satisfactory from the pharmaceutical, physicochemical, antigenic and metabolic aspects. A particle size of $0.5-1 \cdot 0 \mu$ diameter is desirable, and the emulsion must be stable on storage and autoclaving and resistant to oxidation by air. The emulsions must not be flocculated, or damaged, by solutions such as protein hydrolysate or glucose, with which they may be mixed, or by plasma protein. The emulsions must be non-pyrogenic and should produce no local or general tissue reactions. Finally, the metabolic availability of the fat particles must be demonstrated experimentally.

Seventy-four emulsions have been prepared, using plasma protein, formol-treated bovine serum, protein hydrolysate, and dextran in varying combinations with bovine cord phosphatide, brain phosphatide, soya bean phosphatide and cholesterol. Freeze-dried human plasma has been found to yield finely divided emulsions which strongly resemble the natural chylomicron emulsion in physico-chemical properties. Provided that low concentrations of stabilizer are used $(0.4$ per cent plasma protein per 10 per cent oil) the emulsion can be sterilized by heat. Preparations of dextran and bovine cord phosphatide yield satisfactory 30 per cent oil-in-water emulsions, which are tolerated well in acute experiments in doses of $1 \mathrm{ml}$. emulsion per $100 \mathrm{gm}$. body-weight. These emulsions disappear from the circulating blood within $60 \mathrm{~min}$. of intravenous injection, and there is no demonstrable fat embolism. Dr. Elkes stressed the usefulness of these emulsions as a means of studying fat transport and deposition. In these systems the core and the stabilizing film of the emulsion particles can be varied independently. The use of labelled material might be helpful in determining the movement of fat from one part of the body to another. The experiments of Chaikoff, Stare and Shafiroff, and their respective collaborators, augur well for the use of oil-in-water emulsions for parenteral nutrition in man.

A general discussion followed on the matters raised in these five papers. The opening papers will be published in the Proceedings of the Nutrition Society.

\section{WORK OF THE ROCKEFELLER FOUNDATION DURING 1948}

$T$

HE review of the work of the Rockefeller Foundation during $1948^{*}$ opens with a tribute to the opgstan bing reviews which appeared over the signgtur or Tr. Raymond B. Fosdick since 1936 ; but hif Luccssor as president, Mr. Chester I. Barnard, wdr hily maintains the standard set by his immediate predecessor. Mr. Barnard points out that the purpose of the Foundation is to serve the welfare of mankind without national, sectarian or racial discrimination, and that, in a quite informal and undesigned manner, the Foundation has become one of the cross-roads of the scientific, educational and scholarly world. In seventeen countries the Foundation maintains more or less permanent headquarters or research centres. Its officers travel extensively, being in constant touch with scholars, educators, men of science, statesmen, men of affairs and churchmen who seek their detailed judgment and informal advice.

This is the background for the belief that the more personal estimate contained in the president's 'review' should be continued, and Mr. Barnard then gives a brief restatement of the policies of the Foundation and programmes before surveying the outstanding features of the year. In general, the support of the Foundation has been directed to purposes for which it is otherwise difficult to secure funds, and the support has been of an initial or catalytic character with the idea that what has been demonstrated to be useful should then be carried on by other means. Current and palliative types of philanthropy are accordingly left to others, because the needs they encompass are more generally recognized. Further, the Foundation selected as its primary interest the promotion of knowledge and its effective application to human interests. Mr. Barnard instances the history of penicillin as one example of the way in which modest sums made available to scientific research helped to develop a therapeutic agent of great importance.

The parallel with the policy which has guided the trustees of the Nuffield Foundation in Great Britain will be remarked at once, and the whole of this part of the report of the Rockefeller Foundation could well be cited in support of Lord Beveridge's argument as to the place and need for voluntary action in the world to-day (see Nature, October 29, p. 721). $\mathrm{Mr}$. Barnard remarks, moreover, that the Foundation is for the most part a disbursing rather than an oper. ating agency, giving financial support but leaving the execution of the project to governments, universities and other recognized institutions; and he

* Rockefeller Foundation. A Review for 1948. By Chester I Barnard. Pp. 71. (New York: Rockefeller Foundation, 1949.) 
utters a timely warning against the abuse of the word 'research' which, as he truly says, is sometimes used to secure private and public funds for activities more respectable than fruitful.

This position he attributes to the scarcity of qualified workers, which in many important fields, and notably in the social sciences and the humanities, limits the opportunity for support. In outlining the priorities which shape the programme of the Found. ation, Mr. Barnard reviews the secular needs of mankind under the headings: population, communication and co-operation. Population problems are world-wide, ever-present and of first importance. They underlie many critical national, class and racial conflicts, but they are relative rather than absolute, qualitative as well as quantitative.

For many years the Foundation has supported research in genetics, endocrinology, the physiology of reproduction and the sexual behaviour of animals and men. Much of this work is highly technical and of interest chiefly to specialists in the biological sciences and to the medical profession. the studies thus far made are limited in scope and geographical area, and emphasize how meagre present knowledge is and the enormous biological maladjustment for modern man between the sexual drive and the needs of population. Again, human ecology has been slow to develop sustained professional interest, although a study of the characteristics of populations and their interdependence is important in connexion with soil and forest conservation, water control and other means to provide increased support to the human population.

Mr. Barnard refers to the bearing of waste in food supplies and of arable land on the food situation, and to the enormous increase in world capital which more efficient utilization of natural resources and effective co-operation in production demand. $\mathrm{He}$ suggests that in the last analysis the solution of population problems involves the use of all the information we now possess and the acquisition of much more fundamental and practical knowledge. Further, a balanced and simultaneous development along several lines is necessary, and the problems of population lead directly to those of communication and cooperation.

It is becoming more and more clearly understood that the faults and limitations of communication are a fundamental cause of the ills of human society. Misunderstanding and lack of knowledge breed fear and hostilities in even small and intimate groups. Conversely, good understanding based upon intelligible communication is the first step towards co-operation. Mr. Barnard refers to the importance of both the unity of science and the popularization of science from a cultural point of view; but while scientific knowledge provides a fund of exact ideas which forms the basis for a common world, it cannot possibly meet the full requirements of communication. The knowledge of modern languages, the teaching of of them and the extension of the fields of what is to be communicated are also essential, and the Foundation accordingly is interested in the study and teaching of languages, cultural anthropology, political science, history and all that the arts convey of human attitudes and experience.

The capacity to co-operate varies widely among different peoples, and the increased capacity of nations and peoples to co-operate is essential to harmony within the family of nations and for dealing with problems of population. Assuming an effective satisfactory method of co-operation, Mr. Barnard suggests that the capacity for purposeful and conscious collaboration depends upon three broad essentials : first, knowledge based on experience of effective collaboration, involving the techniques required at all levels; second, an attitude of tolerance, not merely of opinion, but also of diverse positions and interests which call for moderation in com. petitive efforts; third, the will to co-operate, which implies an acceptance of fundamental values overriding personal and group interests or the exigencies of the moment. This is the field of ethics, morals, philosophies and religions, and, like his predecessor, Mr. Barnard affirms the belief that there can be no satisfactory solution to the problems of our civilization that does not take into account the ideals and spiritual aspirations of men, concluding his introductory statement with the warning that our efforts to promote the welfare of mankind will promote only disaster if they are not made in the humility appropriate to our ignorance.

The remainder of the review outlines the way in which the Foundation has sought to promote such policies in particular fields. Substantial aid was provided during the year to the Office of Population Research at Princeton University, when the director, Dr. F. W. Notestein, with Dr. J. Trauber of the same organisation, served on a field mission appointed by the Foundation to make an exploratory survey in the Far East. Funds were also appropriated to the Population Association of America for a central office for the International Union for the Study of Population. As part of a concerted effort to raise standards of living throughout the country, the Mexican Government is giving special attention to agricultural experimentation and training, and for this programme the Foundation in 1948 appropriated 327,555 dollars. In Sardinia the Rockefeller Foundation is assisting a large campaign to eradicate the mosquito, while in Crete it is assisting the long-term plan of the Government to improve living standards generally by improving farming techniques, exploiting natural resources and promoting new industry. The Foundation also assisted the government yellow-fever services of Bolivia, Columbia, Peru and Ecuador, and it continued laboratory and field investigations at its Yellow Fever Research Institutes in Entebbe, Uganda, and Lagos, Nigeria.

A number of projects in the basic biology of the nervous system was supported by the Foundation at Western Reserve University, the Cardiff City Mental Hospital, Wales, and the University of Oxford. An additional grant of 750,000 dollars was made to enable the Johns Hopkins School of Hygiene and Public Health to expand its programme, and support of public health institutions throughout the world was continued. To increase Western knowledge of the literary, social and cultural thought of the Near East, the American Council of Learned Societies with aid from the Rockefeller Foundation is undertaking a translation programme. A grant, was made to Cornell University for work in the history of science, and one to Yale University to assist Prof. R. E. Turner to complete his history of major civilizations, entitled "The Great Cultural Traditions". Another grant to Cornell University was for a field experiment in Elmira, New York, on the structure of social relations, while a basic investigation of attitudes and communications is being supported at Yale University. Other grants in the field of human relations were for a field study of the cultural background of Puerto 
Rico, for studies of the loyalty measures in force in the United States, and to the Social Science Research Council to finance study at leading universities on specific ways in which social science analysis can contribute to an understanding of ethical issues and problems of value.

Other grants during the year were for a research programme at Harvard University on the dynamics of personality development, the study of normal Harvard undergraduates from the physical, psychiatric and sociological point of view, and the systematic study of the growth and development of children as individuals. To the California Institute of Technology 700,000 dollars were appropriated for its joint chemistry-biology programme, to the University of Wisconsin 100,000 dollars for equipment of an enzyme institute, and a like sum to the University of California for biochemical equipment. Yale University received 50,000 dollars for studies in plant physiology and genetics, Columbia University 82,500 dollars for studies in genetics and experimental zoology, and Birkbeck College, London, 20,000 dollars towards the construction of an electronic computer for calculating the position of atoms within protein molecules from X-ray crystallographic photographs of these substances.

Since early 1948 the Foundation has participated in a programme for the cultural rehabilitation of Germany and Austria, for which 700,000 dollars was appropriated, part of which is being used by the University of Chicago towards its exchange programme with the University of Frankfort. To help restore scholarly communication between the United States and Austria and Germany, a grant was made to the Germanistic Society of America for subscriptions to periodicals and for the purchase of medical books for German and Austrian universities and research libraries, while the two-way flow of leaders in universities and public life has been aided by other grunts; and by the end of 1948 a con. siderable flow of persons and ideas had been restored between the United States and Germany and Austria, and also the countries of Western Europe. There remains the task of guaranteeing to the ablest young people, the future leaders of all countries, the opportunity of travel in other countries.

Mr. Barnard also refers to the continuing responsibility of the United States and other Western countries to assist the Germans and Austrians in fashioning more democratic institutions and practices throughout their national life. Only when this has been accomplished can they take their place in a peaceful and stable world community. A grant to Columbia University in December 1947 enabled a small group of German radio personnel to visit the United States and later Canada and Great Britain to see the operation of radio in these countries, and in June 1948 a grant was made to the same University to bring over fifteen German journalists for study at the American Press Institute. During the year, 719 fellowships distributed among 47 difierent countries were supported by the Foundation, and of these 399 were administered by the Foundation. For this fellowship programme 1,308,409 dollars were appropriated. The total appropriations for 1948 were $14,897,519$ dollars : of this, $3,000,000$ dollars were for public health, 1,770,000 for medical sciences, $2,800,000$ for natural sciences, 2,230,000 for social sciences and $1,500,000$ each for the humanities and the General Education Board. Of these appropriations 74 per cent was for work in the United States.
LOCALIZATION OF SOME HYDROGEN-ACTIVATING ENZYMES IN INSECTS DURING METAMORPHOSIS

\author{
By DR. I. P. S AGRELL \\ Department of Zoophysiology, University of Lund
}

$\mathrm{A}$ $\mathrm{S}$ a link in a/continuous study of the intermediate metabolism during insect metamorphosis, I hay also made an attempt to determine the localization of some dehydrogenases. Pupæ of Calliphora erythrocephala Meig. in all developmental stage have been used as the material of investigation.

1. uscle formation occurs principally in the thorax. In the abdomen the amount of musculature at hatching is less than one per cent of that in the thorax. A contrast is afforded by the larval fat body, which at the formation of the puparium is about equally well developed in both the thorax and the abdomen. During the metamorphic period, however, from about 30 per cent of the pupal life, the larval fat body in the thorax is successively substituted by musculature. Finally, it is apparently wholly transformed into muscle tissue. In the abdomen, on the other hand, at hatching the main part of the tissues is the disintegrated fat body. Thus it was thought that by dividing the pupæ into parts, the head, the thorax and the abdomen, and then studying the enzyme systems in these parts, it should be possible to analyse the oxidative metabolism in more detail and to decide which dehydrogenases are muscle enzymes and which are fat-body enzymes.

The division of the pupæ is easily performed after instantaneous freezing by carbon dioxide. Measurements of the enzyme activity are made with the methylene-blue method of Thunberg. For the determination of the total dehydrogenase activity, that is, the spontaneous activity, the following reagents were placed in each tube: $0.25 \mathrm{ml}$. methylene blue in a concentration of $1: 25,000,0.75 \mathrm{ml}$. phosphate buffer of $M / 15$ and $p H 7 \cdot 2$, and the appropriate parts from two pupæ. For determination of the activity of individual apodehydrogenases, the pupal mass was washed three times with $10 \mathrm{ml}$. distilled water and each time centrifuged; the respective donor substance $(M / 10)$ was substituted for $0.3 \mathrm{ml}$. of the buffer, and if necessary a codehydrogenase I preparation of 30 per cent purity in a concentration of 0.1 per mille was added. The preparation may also contain codehydrogenase II, because it acts upon the citric dehydrogenase. In these experiments, parts of two to four pupæ were used; but all values given are valid for two pupæ. The enzyme activity is expressed as the rate of methylene blue reduction $(100 \times$ the inverse value of decolorization time). The results are represented in Fig. 1. Each separate curve is drawn from the results of five tube tests repeated at intervals of 10 per cent of the pupal period.

If, at first, the spontaneous dehydrogenase activity is taken into consideration, it is evident that the rising part of the previously established U-shaped curve for this activity during metamorphosis and, therefore, also probably for the whole pupal tissue respiration (cf. Agrelli), represents mainly an increasing activity of dehydrogenases in the thorax. (Note the logarithmic scale used in the diagrams.) At hatching, nearly 90 per cent of this activity can 